\title{
Interview with Elem Klimov
}

By Ron Holloway

Spring 2008 Issue of KINEMA

Interview with Elem Klimov at the Denver International Film Festival 1986

Ron Holloway: Elem, how many films have you made up to now?

Elem Klimov: Over the past 20 years, I have made six feature-length films and one short film lasting only 18 minutes, a film called Larisa (1980). It's a biography of my wife, Larisa Shepitko (1938-1979). It was made as a tribute to the filmmaker Larisa Shepitko. A small film - but one of the most difficult films of my life.

Which is your favourite among the feature films?

None.

Which then was the easiest film to make? Or the most difficult?

None of them were very easy to make. Maybe Sport, Sport, Sport (1970) was the easiest, but that was because I didn't take it very seriously. And the most difficult one among the serious films was definitely Idi I smotri (Come and See, 1985).

\section{On the making of Agoniya (Agony, 1975-81)}

How long did it take to make Agony from the screenplay to the official release of the film? The history of the making of Agony began back in 1966. That's when I started to write the screenplay, together with Semyon Lungin and Ilya Nusinov. We had to fight for seven or eight years to get the script approved. On two occasions, we tried to shoot the film. On the first try, it was stopped. We tried again to make the film, but once more it was stopped. Finally, on the third try, I actually could make the film. But then it could not be shown officially for ten years. It had been put on the shelf - a film without an audience.

What kind of problems did you have with the government censors when they saw Agony? I think they had problems with both Tsar Nicholas and with Rasputin. At least, that's what I heard, because the reasons were never told to me directly. The main problem with the film was that there was too much Rasputin in it. That is, the historical weight of the film was centred in the problems dealing with Rasputin. As far as Tsar Nicholas was concerned, everyone was expecting to see a caricature. Whereas we, even though we took a negative position, presented Tsar Nicholas as a human being.

Since Agony was originally intended for release in 1977, during the $60^{\text {th }}$ anniversary celebrations of the October Revolution, you were allowed to research the historical figures of Grigory Rasputin and Tsar Nicholas II in the Soviet archives. How long did this research take? And what did you discover there?

The biggest part of the job was my work in the archives. We spent many, many months there, the screenplay writers and myself. We read tons of different documents. We researched the private photo albums of Tsar Nicholas. And we looked at - and even held in our hands - some of the small paintings done by the tsar. These paintings didn't show any signs of talent at all. In fact, they were complete without talent. As for the pictures that Tsar Nicholas was so interested in - the photographs in the family album - they were also the work of a man without any talent at all.

Tsar Nicholas II was just a nice human being. He was a good father, a good family man. He liked to drink, He liked to spend time with his friends, with his officers. But he didn't have any talent to be a leader. And he definitely didn't have the talent to be the leader of a gigantic country at this critical historical moment. And that is why the discrepancy between the tasks facing Tsar Nicholas and who he was - a nice family man - led to a lot of catastrophic events in this country, led to a lot of blood. The Russian people refer to him, the only one among all the Russian tsars, as "Bloody Nicholas." 
How did Soviet officials and the general public react to the sexuality in the film? Was it considered by some to be "too excessive"?

(laughs) I don't think the film has too much sexuality in it. In my opinion, there is very little in it. Besides, how could you even tell the story of Rasputin without showing this sexuality? To tell you the truth, I don't think it was sexual enough! But compared with our traditional, completely sexless movies, I'm sure that even this little bit of sexuality was a shock to some.

You said some critics felt that Tsar Nicholas was presented too sympathetically in your film. How do you react to this criticism?

We tried to show Tsar Nicholas as a real human being. As a simple man - intelligent, well brought up, with good manners. But we also placed historical demands on him. And I think this was depicted well enough in the film. So the task that Anatoli Romashin had facing him as an actor was to play an intelligent, well mannered man, whom the people called "Bloody Nicholas." The worst thing to do in this case would be to show him as a vampire with bloody teeth. That would be a real caricature. But we chose a more complicated way to present the figure. And that is what the film is all about. That's what our aim was.

Were you asked to cut passages out of Agony? If so, how did you respond?

A rumour has been going around in this country, and in the West, that a Soviet government official has the right to cut films before release. I can assure you that this is not the truth. The right to cut, or not to cut, a passage out of a film belongs only to the film director - nobody else. And the directors differ among themselves. There are those who allow cuts to be made in their films. And those who don't. You are looking at a person who never cuts his films - or cuts them very, very little. I did not cut this film. Besides, nobody outside of myself could do it. This is an ethical question.

Do you feel that Agony may have lost some of its initial impact due to its late release nearly a decade after its completion?

Yes, no doubt about it. In the film world, as in real life, the atmosphere around us - I call it "air" - changes very fast. In the cinema styles change very fast too. So if a film is not shown shortly after it has been completed, then it becomes outdated very, very soon. And there is no longer any correspondence to new thoughts, to new levels of thinking. So if the film has not been shown for as long as ten years, then I think it is a real tragedy. For cinema has its own dramatic principles.

Take Agony, for example. What happened when the film was shown to the public for the first time after ten years will give you an idea why I am against it. When we started making the film ten years before, the figure of Rasputin was very important to me. I wanted Rasputin to be played by an entirely unknown actor, one not known to anybody. A kind of "sphinx," whose face could not be identified with any other roles. But now, in the ten years since the film has been released, the same actor - Alexei Petrenko - has taken part in other films. So today, when the public sees this actor playing Rasputin, the reaction is: "Oh, we know him. He's played so many other roles. And now he's playing Rasputin!" That's why the experience was so anti-climatic when the film was shown ten years later.

Did the two actors who played Rasputin and Tsar Nicholas, Alexei Petrenko and Anatoli Romashin, come from the theatre? How did you discover them? And how did you decide that both were right for their roles?

Both actors come from the theatre. Anatoli Romashin, who played Tsar Nicholas, had played several roles on the stage, but he hadn't as yet any distinct success in the cinema until he played Tsar Nicholas. As for Alexei Petrenko, who played Rasputin, he was working at that time in Leningrad when I discovered him for Rasputin. I'm rather proud of making that discovery. This was his debut in cinematography and the beginning of a new career.

The story of Rasputin has been treated at least a dozen times in American films. In your preparation for Agony did you view any of these films? Or other "Rasputin films" produced in other foreign countries?

I saw about seven films about Rasputin. Among these were a French one, an American movie, one made in Germany too. To tell you the truth, I couldn't take any of these films seriously. It's impossible to make a film about Rasputin and not make it in Russia. It's simply impossible. In the same way, it's not possible to make a film in Russia about some American historical figure. This is nonsense. That's why none of these 
films prove to be convincing. None of them.

Did you find any footage in the Soviet film archives, like old newsreels, that helped you to bring an extra authenticity to Agony? I'm referring to some documentary footage on the Romanovs and the October Revolution.

As a matter of fact, in the making of Agony I used as background material a lot of documentary footage found in our own and in French film archives. The use of the documentary footage played a very important role in the making of this film. Otherwise, what would have happened? The whole thing would have become a simple intrigue in the tsar's palace. But the presence of the documentary footage, on the other hand, made it a real historical event.

What do the authentic records show about the actual killing of Rasputin? How many attempts on his life were made? And which one finally succeeded?

Because we now have access to the archival records, we are able to tell the true story. It happened as follows: The bloody deed was long in preparation. The main person in the plot to kill the monk Grigory Rasputin was Prince Felix Yusupov. Another was the Grand Duke Dmitry Pavlovich, who had planned for a long time to kill Rasputin. But neither of them could agree on the date because one or other was busy at the time. Finally, they could agree on a date. Vladimir Purishkevich, a Duma Deputy, and Lieutenant Sukhotin, a young military officer, joined them in the plot. These four people prepared the poison, selected the rendezvous, and deceived Rasputin by telling him that at this place he would be able to meet Irina Yusupova. But she was actually at that time in the Crimea.

So, to make a long story short, Rasputin did show up at the appointed place and was then poisoned with two different doses. One type of poison was potassium cyanide, which they put into a cake. The other, hydrocyanic acid, was put into the wine. Both doses of poison were in great quantities. Nevertheless, they didn't affect Rasputin at all. He only began to have hiccups. He became light-headed. But he didn't die. Nothing at all seemed to happen to him! And this led to a lot of panic among the members of the murder plot.

After a conference amongst themselves, Yusupov returned downstairs again to where Rasputin was, and shot him in the back. Rasputin fell down, and he looked like he was dead. Then a great panic broke out. They began to tear down the drapes from the windows in Yusupov's palace. They intended to wrap Rasputin's corpse in drapes that bore the Prince's initials. But when they returned downstairs, they found that Rasputin wasn't there anymore. Somehow, somewhere, he had disappeared. Then Purishkevich ran out of the house and found Rasputin in the courtyard. At close range he fired three more bullets into his back. Rasputin fell down, and it looked like he had finally died.

They then took Rasputin's body back into the house, where a lot of hysterical things happened. They hit Rasputin on the head with heavy weights. They kicked him several times. And finally his body was taken in a car and thrown into the Neva River. Before falling into the water, he hit his head on the bridge. He broke the ice and went immediately underwater. How Rasputin really died was rather mysterious, very mystical. According to a doctor, who examined the body after it was recovered from the river, a lot of mystery surrounded the circumstances of his death. For he was apparently still breathing for 40 minutes after that whole murderous affair! Finally, however, he was really dead.

Among all the murders recorded in history, Rasputin's ranks as the most unusual. Until now, it remains a mystery. Just what could have kept him alive for such a long time? Was it his unusual strength? Or was it because he had been given a very large amount of poison? Sometimes one poison can neutralize another. Perhaps the poison in the cake was neutralized by the fat in the cake. It's still unknown as to what really happened.

It's often said that Rasputin had mystical powers. Does this perhaps explain how he was able to initially survive the murder attempts?

No, I don't think there was anything mystical about it at all. I think we have a tendency to call mystical everything we don't as yet know anything about. Things about which we haven't yet learned enough about. Perhaps sometime in the $21^{\text {st }}$ century we will know more about our makeup as human beings. And then we won't be using the word "mystical" any more at all. Of course, some human beings, more than others, 
possess some unknown hidden strength that's not yet fully researched, that we don't know much about save that it is there. And sometimes these hidden strengths come visibly to the surface. Rasputin was just this type of strong - very solidly strong - human being. As a matter of fact, I once researched the last year of his life. And no normal human being could have withstood what Rasputin was able to go through. He managed to sleep only two to three hours a night. Yet he managed to stay very, very active at the same time. This shows that he was an extraordinary human being. He possessed enormous amounts of strength.

If you had the chance to make Agony again, would you wish to change anything in the film? I would have changed the film completely. When Agony was finished in 1975, and I looked at it, I wanted to redo it almost immediately. I am always the first critic of my films. Not only the first critic, but the hardest critic of myself as a filmmaker. As a matter of fact, I made an agreement with one of our film journals that when Agony would be released to the public, I wanted to have the chance to write the first critical article about the film. Anyway, the history of Agony turned out to be different than I had imagined. So, in the end, I really didn't have to write anything critical about it at all.

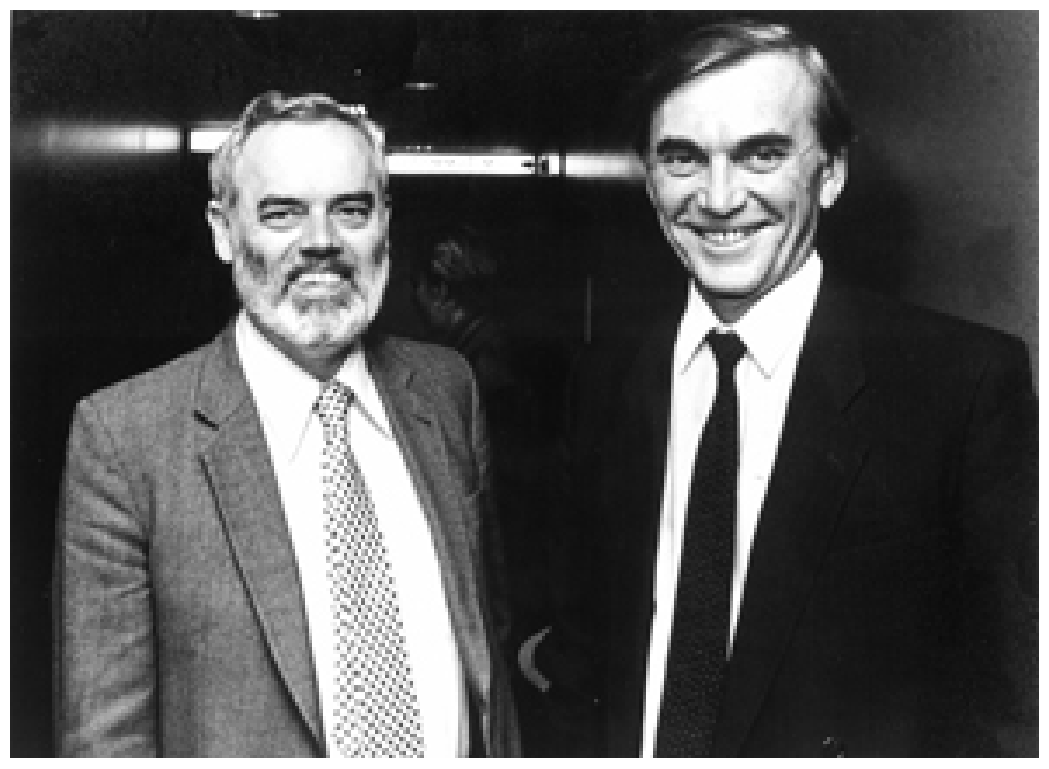

Figure 1: Director Elem Klimov (1933-2003) (r.), with Ron Holloway

On the making of Proshchanie (Farewell, 1981/83)

When you took over the film adaptation of Valentin Rasputin's novel Proshchanie s Matyoroy (Farewell to Matyora), begun by the late Larisa Shepitko, you changed the title to Farewell as a homage to your wife. Did you find it necessary to change the original concept for the style of the film?

We have to keep in mind that the original thoughts and ideas about the making of Farewell to Matyora belonged to Larisa and her friends. So, after their deaths - after the entire film crew had died in a tragic car accident in 1979 while shooting on location - these thoughts and ideas vanished with them. You cannot put a concept for a film down of paper, or put the original design into a simple drawing. It's not to be found in a screenplay either. So that's why - after their deaths - all this vanished with them. And that's why we had to start from scratch. We had to make a film in a very short, limited space of time. We had to change the script, to choose a new style. This is not to mention that I was holding meetings with the cameraman and the production designer while under the stress placed upon me by the death of my wife. It's best not even to recall the feelings I had at that time.

In any case, all that I've mentioned affected the quality of the film. And I'm very critical of it. Just as I'm sure that if Larisa had made Farewell to Matyora, it would have proved to be a much more interesting film - simply because she had carried the thoughts about this film around with her in her head for a long time. She was ready to give birth to the film, not just to shoot it. In the end, we were not able to do more than 
what we did. And I think we did the right thing by dedicating this film as a memory to dear lost friends, while addressing ourselves at the same time to the problems discussed and described by Valentin Rasputin in his novel.

The critics in the Soviet Union came down pretty hard on Farewell. What was Valentin Rasputin's comment upon seeing the film?

I feel uncomfortable in repeating what he said. For actually he was very complimentary about the film. You see, when Larisa went to him for permission to adapt the novel to the screen, he really did not want anybody to make a film version from it at all. This was because he viewed it as an unusual form of literature. Something very subtle and done in a refined style. Alexei Demovich, an excellent critic, referred to Farewell to Matyora as "twinkling prose." It's something you can't really touch, or hold in your hand. Cinema, on the other hand, is a rough visual art. How can you then transfer "air" to the screen? How can you express the depth of feelings, of internal monologues, on the screen? That's why it was very rewarding to me when Valentin Rasputin said he liked the film and praised it. Although I myself know that Farewell was far from perfect. And that it could not be compared to his novel.

You've talked on occasions with Premier Mikhail Gorbachev about the status of contemporary Soviet cinema. What were his comments on Farewell?

Mikhail Gorbachev takes a great interest in Soviet cinema. When he viewed Farewell, I had a long discussion with him about that film. Also, about my films Agony and Come and See. He went into concise details about Farewell. He compared the film version to the original novel by Valentin Rasputin. He said that he had read all of Rasputin's novels. I discovered that he loves films, loves cinematography. He likes going to see serious films. He analyzes films deeply and seriously. But he also loves the theatre. He goes often to the theatre. This was a pleasant discovery for me. He's a person who will make a big difference in the development of our cinematography. He values and loves the art of cinema, as well as art in general. For him this is something serious.

What exactly did Mikhail Gorbachev discuss with you about the film and the novel?

As I said, he has read all the stories written by Valentin Rasputin. In regard to Farewell, we talked about the way the film was made, and we mutually compared the film with the novel. We talked about the problems that were depicted in the film. So I found out that a lot of new things were being planned for the future. For instance, the plans in regard to old Russian villages. It's planned to revive many of the villages that had been abandoned years ago and have now fell into ruins. For they are still historical places, villages once inhabited by our ancestors for hundreds of years. These places were not chosen by accident. Nature graced them with lasting beauty. So everything is being done right now to bring the old villages back to life. Roads, too, have been rebuilt to reach many of these places. But the villages themselves have to be modernized so that people will be able to return back to them.

Do you consider Valentin Rasputin's Farewell to Matyora to be a modern classic in contemporary Soviet literature?

In my opinion, this novel by Rasputin is the deepest and the most perfect he has written. I like all his novels. From his first one, Den'gi dlia Marii (Money for Maria, published in 1967), to his latest. But I think that Farewell to Matyora stands as the peak of his art.

\section{On contemporary Russian and Soviet literature}

How do you view the work of other contemporary Soviet writers? Authors like Yuri Trifonov, whose Dom na naberezhnoy (The House on the Embankment), published in 1976, appeared at the same time as Farewell to Matyora. Or Vasil Bykov, who wrote Sotnikov and other fine war stories.

The late Yuri Trifonov (1925-1981) was one of our great modern writers. Also, Vasil Bykov (1924-2003), the Belarusian author. Both will be remembered as very honest, talented, truthful writers. Bykov always treated the war as his theme, while Trifonov dealt exclusively with stories about city life. Both rank internationally as very well respected authors, I should add.

Larisa Shepitko's film Voskhozhdenie (The Ascent, 1976) was based on Vasil Bykov's Sotnikov 
(published in 1970). How was The Ascent received in the Soviet Union as a new type of war film?

As a matter of fact, this was one of those rare occasions when a book adapted to the screen turns out to be no worse than the original. By that, I mean that the film was just as good as the novel. And in some ways it even enriched the material in the book. When the film was released, it was greeted as a great achievement in the artistic life of our country. You yourself witnessed what an important role The Ascent played at the Berlinale back in 1977. It won not only the Golden Bear, but several other prizes as well.

The Ascent burst upon the Soviet film scene like a bombshell. Because, I think, something new was being said about the war. Here was a new approach to showing the psychological changes that can occur in a human being during the war. It contained much more than just another story about two partisans during the war who were captured. So I would say that it was a kind of turning point in Soviet cinematography so far as the war theme was concerned.

The Soviet Union can boast of a number of respected writers. Besides Valentin Rasputin (born in 1937), you have already mentioned Yuri Trifonov (1925-1981) and Vasil Bykov (1924-2003). Who are some of the writers you consider important for the future of Soviet literature and cinematography?

Every film director has his own favourite writers, particularly when it comes to adapting their works for the screen. As for myself, my favourite writers are among the most interesting in literary circles right now. Valentin Rasputin, of course. Also, Viktor Astafiev (1924-2001) and Sergei Zalygin (1913-2000), the editor of Novyi Mir. Others are Vasily Belov (born in 1932) and Chingiz Aitmatov (born in 1928). Among the new generation of writers are Vladimir Krupin (born in 1941), Vladimir Makanin (born in 1937), and Anatoli Kim (born in 1939). Right now, we have a lot of interesting writers. What's nice is that each of them has a different face, a different style.

Also, you can expect a certain style of writing from an author like Valentin Rasputin. Something along the lines of what he had written before. Yet in each of his four novels he managed to reproduce four contrasting dimensions. That's something very difficult to accomplish in literature. Now he's written a new novel, Pozha (Fire, published in 1985). And, again, it's a new Rasputin, a completely new one. He also writes articles. In this way life becomes full of surprises. Pleasant surprises that writers give us.

\section{Will any of these writers turn their talents to writing screenplays as well?}

Thank God, they're busy with their own literature and working on their own stories. But they often seek out screenwriters to adapt their works for the cinema. That's a correct and appropriate thing to do. Screenwriting is a very special kind of literature. A cinematographic literature is entirely different from the regular form of literature. It has to be written by professional screenwriters, not by writers as such.

I recently viewed Tengiz Abuladze's Monanieba (Repentance), a Georgian TV production that dealt with the Personality Cult in a manner seldom attempted before in Soviet cinema. Can Stalinism as a theme be presented on the screen in the Soviet Union without fear or apprehension of any kind on the part of the director?

Without any fear at all! It's true that this topic was never touched upon before. Nor was it discussed at all for a long time. Tengiz Abuladze approached the subject indirectly. Allegorically. Artistically. And the result was a very original film called Repentance. It was made two years ago for Georgian television. But now it will be released for cinemas as well. That's the way it should be. Because then the film will be seen by the mass public as an original film by a talented director. And I am sure that it will be appreciated a lot by everyone who goes to see it.

There's another film like it in preparation. It's based on a novel by Vasil Bykov called Znak bedy (The Sign of Disaster, 1985). It's directed by Mikhail Ptashuk. The subject matter is similar. So the sort of theme isn't taboo at all in our cinematography. Nevertheless, in treating this topic on the screen, and in underscoring the importance of the historical moment, you have to take the trouble and be very exact. So as not to mix up any of the facts. You have to be careful, too, in presenting the released film. So, to answer your question, let me say that it's really important to explore the theme. But it also has to be done with a lot of thought.

On the making of Idi I smotri (Come and See, 1985) 


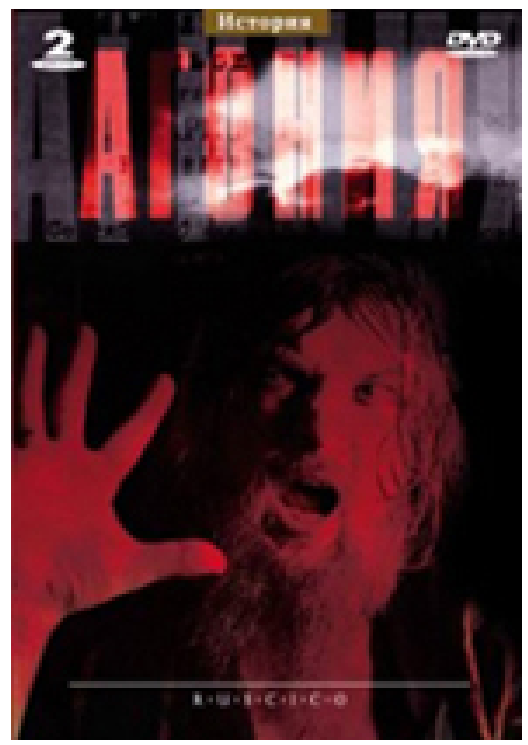

Figure 2: Klimov's Agoniya (Rasputin, 1981) DVD

While Larisa Shepitko was shooting The Ascent (1976), you were working on the screenplay for Come and See (1985). Both films are set in Belarus during the horrific war years. Were these two projects conscious efforts to reorganize and rejuvenate the war theme in contemporary Soviet cinema?

Let me first say that the events depicted in Larisa's The Ascent may have happened in Belarus. But the film itself was not shot there. It was shot in the Russian town of Morum, in the forest near Morum, and in the Mosfilm Studios. Whereas my film, Come and See, was shot only on Belarusian soil. The events with the people, the peasants, actually happened as shown in the film. Come and See doesn't have any professional actors. Even the language spoken in the film is Belarusian. What was important was that all the events depicted in the film really did happen in Belarus.

All the same. Your own autobiographical experiences seem to surface as well in Come and See. Were some scenes triggered by your own memories of the war years? Or was the film based entirely on the experiences recorded by Ales Adamovich (1927-1994) in Khatynskaya Povest (The Katyn Story), his 1972 book of Belarusian war memories?

To be more exact, it was some kind of reflection of what I felt of my own emotions at the time of the war. Or, you might say, of my wartime childhood. Because when the war started, I was only eight years old. I was born and raised in Stalingrad. So, like a lot of my friends and acquaintances, we all experienced together very hard times. We had to work hard. We felt human suffering. These were my memories of the war. Memories that will never leave me. And I am sure that, one way or another, they were reflected in the film Come and See.

But even stronger, and far more sharply etched in his memory, were those experiences of the writer Ales Adamovich, upon which the film Come and See is based. Ales Adamovich was the same age as the main hero in the film. He and his family fought with the partisans and witnessed the genocide perpetrated by the Nazis on Belarusian soil.

The stylistic elements in Come and See are striking. It goes from realism to surrealism. It gradually unfolds into an horrific visit of war. What were your aims? To make a war film? Or something entirely different from other war films?

On the one hand, Come and See is a memory about war. A people's memory about the war. And it was meant to be a people's film. That is, the recollections of the most horrible moments of the war. On the other hand, the main thrust, the main point, of this film was directed towards the present. It stands as a warning for all about war itself. Or, I might say, a passionate warning against war. A Japanese friend, upon 
seeing the film at the Moscow film festival, said: "Your Belarusian village is like our Hiroshima. And that the whole world could once again become an Hiroshima."

So what you're saying is that Come and See is an antiwar war?

To come right to the point, Come and See is both an antifascist film and an antiwar film. Although some have also implied that it is an anti-German film, too. This is not true. It was never meant to be an anti-German film. So I'll emphasize it once more: it is an antifascist and an antiwar film. Another very important purpose in the making of that film was to talk about a human being. What is a human being all about? What are the limitations of a human being? What are the extremes to which a human being can be brought?

As Dostoevski once wrote: "A human being is a beast in you that you can face, and it faces you." A human being under certain circumstances can discover in himself some horrible things. That he, as a human being, can fall so low. That is what I tried to depict in Come and See. And that's why we set out to show in the film a human being near his limits. And sometimes even beyond his limits. To show just what is a human being. And such a task - these very questions - are the most important in the world of art.

How did you achieve the stylistic colours in Come and See? It seems that even the film laboratory played an important role in the film's stylistic conception.

We had before us a complicated task in the making of the film. At a certain point in Come and See its "creators" simply had to disappear. By that, I mean that we shouldn't be thinking about being a director, a cameraman, actors, or film professionals. All this had to dissolve into the action itself. In order to accomplish this, we had to be realistic to the maximum. It's almost like making a documentary, but our method was not to copy the documentary style or even the process of making a documentary. That's why we decided not to make a black-and-white film. Because in the past everyone in our country thought that a film about war had to be made in black-and-white. Even that the war had to be imagined in black-and-white.

Our position, on the other hand, was that the war, and life as it went on during the war, were both full of different colours. I even found a German newsreel documentary - titled Signal - that had been filmed on colour stock. In fact, I viewed many war films - all fascist war films made by the Germans - that had also been filmed in colour. But at the same time we didn't want to make a colour film, strictly speaking. We only wanted it to be colored - that is, of a darker colour, or a kind of softer colour. So the cinematographer did everything he could to present on the screen a colour film but made in black-and-white. And at the same time not making use of black-and-white film stock. The task was difficult, for everything had to be done so thoroughly. But I think that Alexei Rodionov, our cameraman, managed it all very well.

\section{On "glasnost" at the Union of Soviet Filmmakers}

Currently there is a new spirit of openness - of glasnost - pervading the arts in the Soviet Union. This is particularly true of cinema and literature. Such a spirit has occurred before in the Soviet Union. Do you feel that this new movement towards liberality is irrevocable? Can your government put aside censorship completely?

As long as we continue to hope and believe that it should remain this way, and take upon ourselves the responsibility to make it happen, the new spirit will continue. Every person should feel a responsibility towards it. As far as the Union of Soviet Filmmakers is concerned, there are many newly elected people in a position to work towards this goal.

Your election in May of 1986 as First Secretary of the Union of Soviet Filmmakers was considered by many to be nothing short of a "revolution." How do you view your election?

(laughs) It is not myself that really matters. The situation in the country is changing for the better right now. It started to change about a year ago. The important moment occurred at the 27th Congress of the Communist Party of the Soviet Union - held from 25 February to 6 March 1986 - followed by the 5th Congress of Soviet Cinematography, which took place immediately after the Party's 27th Congress. Many changes that are now happening in different areas of our society are connected to the results of the 27th Congress. These changes are, of course, revolutionary. Not only in our cinematography. But also in other areas of life as well.

All the same, can censorship in the Soviet Union really remain something of the past? Where are the limits of this revolution to be found? 
The editorial boards of film journals, as well as film and stage directors, are ultimately responsible for their own actions and decisions. Self-censorship, if you will. Nobody is supposed to watch over them any more.

Are you happy with your job as First Secretary? Wouldn't you rather be making films?

I would much rather not have my present job. I didn't want this job in the first place. I think - but maybe I'm mistaken - that I am cut out to be a film director. And I want to be seriously engaged full time in the making of films. But the new job distracts me from that. We now put in long hours of work - on weekends, and without any rest. But this is a special moment right now. A lot of changes have to be made quickly. We can't afford to waste any time at all. The past cannot be repeated. Right now, I am completely absorbed in this new job. But I hope that perhaps next year I will be able to start a new film.

May I ask you to name some of the most talented film directors working today in the Soviet Union? Also, which kind of Soviet films should foreigners take a particular interest in seeing? To be concise: truthful films by talented directors. Nearly all films made by talented directors are truthful in any case. Presently, we have a lot of talented directors working in our country who are making these kind of films. Filmmakers who are not yet known abroad. And we have been making such films in the past in spite of all kinds of difficulties and obstacles. But now it will be much easier for them.

Among those directors to be singled out for the high quality of their work are Alexei Gherman and Gleb Panfilov. I like their films very much. And I would be pleased if their films could also be seen abroad, particularly in the United States. I also like the films of Sergei Parajanov, Otar Ioseliani, Eldar and Georgi Shengelaya, and some films by talented Kirghiz directors. I would also like to see the films of Kira Muratova shown in the United States. She's a talented director from Odessa, whose films we are helping to get released through the Conflict Commission at the Union of Soviet Filmmakers.

The same is true of a new Leningrad director, Alexander Sokurov. Until now, he has not succeeded to get any of his films released in the Soviet Union. He just hasn't had any luck. Or, you might say, fate has played tricks on him. Although he has made both documentary and feature films. And very interesting films, I might add. He is a very original director. These are just some directors whose films deserve to be seen.

Now that changes are evident in the Soviet film industry, have foreign buyers shown more interest in distributing films by the talented Soviet directors you just mentioned?

What's unfortunate is that our modern cinematography is practically unknown abroad. Particularly to Americans. On the other hand, we in the Soviet Union are quite familiar with American cinema. American films - even those that are not particularly good - do get shown in the Soviet Union. But the American public has no idea at all about what's going on in Soviet cinema. I hope that this will change for the better in the future. Because I do believe that through the cinema it is possible to learn a lot about the culture of a particular country. About the life of the people in that country. Cinema can break the ice of animosity and misunderstanding between two countries. It can play a very important role in bettering relations between the Soviet Union and the United States.

The late Vladimir Vysotsky (1938-1980) made a name for himself in the Soviet Union as an actor and a balladeer. He played Hamlet at the Taganka Theatre in Moscow. And he was sometimes referred to as a typical Hemingway hero. Since you knew him personally, how do you view him as an original talent?

We were very good friends for a very long time. We enjoyed a quite warm relationship. He was a universal talent, a unique personality. A combination of actor, artist, singer, writer, composer. Besides this, he was just a wonderful, honest, and completely charming human being. So, to make it short, I can say that my feelings towards Vladimir Vysotsky were nothing but positive, very positive, until his sudden death of a heart attack in 1980 at the age of 42 .

If I am not mistaken, you can hear the voice of Vladimir Vysotsky singing in the background of your film Farewell.

Yes, he sings one of his well known ballads. I used it on the soundtrack as a kind of commentary.

\section{On Soviet-American Film Relations}

During your current trip through the United States, you have been able to meet several Amer- 
ican film colleagues. Is there any possibility of broadening the contacts between the Soviet Union and the United States in the near future?

I came to the United States with my colleague, the Armenian director Albert Mkrtchian. We've been travelling for twelve days already. And now I am attending the Denver film festival to introduce a retrospective of my films. During these twelve days a lot of things have been happening. We've gathered a lot of impressions. Interesting impressions. From just meeting people to becoming better acquainted with life in the United States. But the most important thing for us, of course, was the chance to meet our American colleagues. Film directors, producers, actors. We've come to realize that their interests are much the same as ours. And that they, too, would like to establish serious contacts between our two countries. We've discussed several ideas as to how to do this.

As a matter of fact, one idea in particular. We want to organize a combined celebration on New Year's Eve with American and Soviet cinematographies via satellite television. In other words, a "tele-bridge." It can turn out to be an interesting show with an important discussion taking place at the same time. I hope we will be able to accomplish this. We're making the effort now from both sides. But if we cannot organize it this year, then perhaps we'll do it in 1987 instead. But we are definitely going to do it. At least, I am positive that now is the right moment to bring this idea to realization. Right now, the water in the ocean between the two countries has become warmer. And it's important to cross bridges. There no other way but to do it. There's no other way to save the world.

What are some impressions you've gathered during this trip to the United States? This is my first visit to the United States. And I must say that a lot of things amaze me. I had gathered some impressions before from American movies. And I read a lot about the United States. But when you see the country with your own eyes, it's completely different. I like American movies. I like when a lot of things surprise me. I fell in love with San Francisco. It's an amazingly clean, light, bright city. A city with a happy dream.

Thank you for the interview, Elem. And all the best for the rest of your trip.

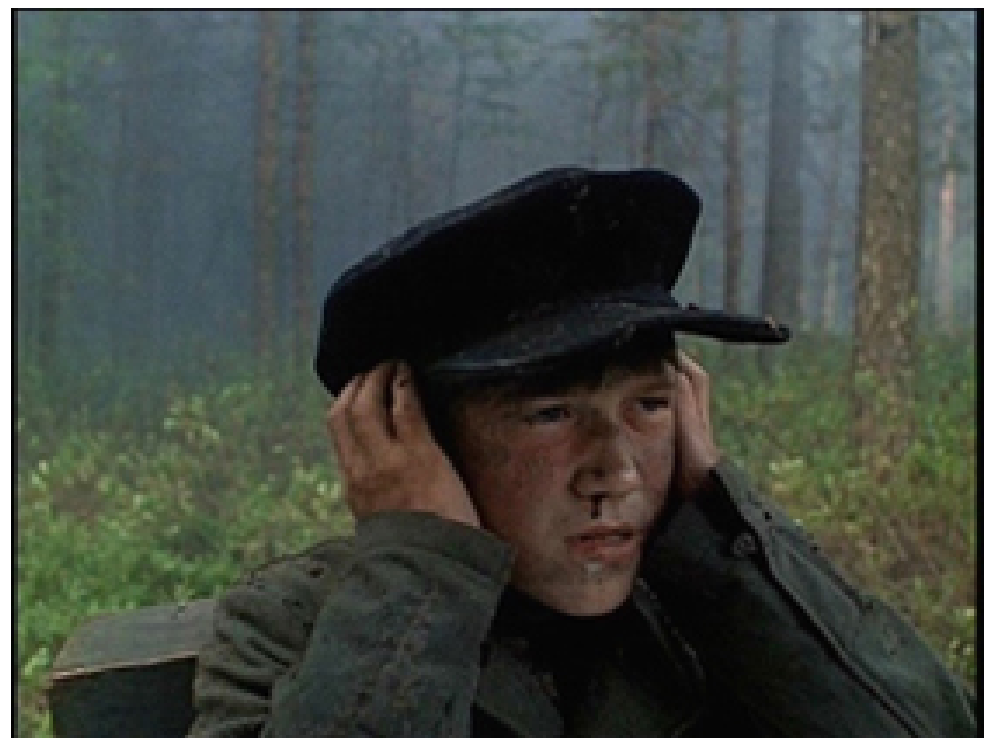

Figure 3: Idi i smotri (Go and See, 1985) by Elen Klimov

\section{References}

The above is original text for the documentary Klimov (Germany-UK, 1988), a documentary on Russian director Elem Klimov (1933-2003)

Interview, script and direction by Ron Holloway

Produced by Dorothea Holloway, KINO Productions, in co-production with Channel Four (London) 


\section{Author Information}

Ron HOLLOWAY (1933-2009) was an American critic, film historian, filmmaker and correspondent who adopted Europe as his home in the early fifties and spent much of his life in Berlin. He was an expert on the study of German cinema and against all odds produced, with his wife Dorothea, the journal German Film, keeping us up-to-date with the work of directors, producers and writers and the showing of German films around the world.

In 2007, Ron Holloway and his wife were awarded the Berlinale Camera Award. Ron also received the Bundesverdienstkreuz (German Cross of Merit), Polish Rings, Cannes Gold Medaille, the American Cinema Foundation Award, the Diploma for Support of Russian Cinema and an honorary award from the German Film Critics' Association.

Ron was also a valued contributor to Kinema for the past fifteen years. 